\title{
KURIOS
}

(Jurnal Teologi dan Pendidikan Agama Kristen)

Vol. 2, No. 1, Oktober 2014 (62-69)

ISSN 2406-8306 (print)

http://www.sttpb.ac.id/e-journal/index.php/kurios

\section{Membentuk Karakter Kristen Pada Anak Keluarga Kristen}

\author{
Handreas Hartono
}

Sekolah Tinggi Teologi Pelita Bangsa Jakarta

\section{Pendahuluan}

Membentuk karakter kristen pada anak keluarga kristen kedengarannya tidaklah luar biasa karena tidak mungkin orang tua kristen akan membentuk karakter yang tidak sesuai dengan identitas orang tua. Karakter berguna dalam segala aspek kehidupan karena menjadikan orang berintegritas, berpengaruh dan menjadi saksi Kristus yang efektif. Namun kenyataannya begitu banyak anak-anak kristen yang memiliki karakter tidak baik, banyak orang kristen yang di penjara, bahkan anak pendeta yang menjadi batu sandungan dimanamana.

Menurut kamus besar bahasa Indonesia, karakter didefinisikan sebagai tabiat; sifatsifat kejiwaan, akhlak atau budi pekerti yg membedakan seseorang dengan yang lain; watak. Kata karakter dalam Alkitab berasal dari kata Yunani yang berarti alat ukir atau alat pemahat. Dalam bahasa latin, karakter bermakna: "tools for marking, to engrave." Webster Dictionary memberi arti, "engrave, inscribe."

Dengan pengertian di atas dapat dikatakan bahwa karakter adalah "proses memahat jiwa, menandai diri atau mengukir diri sedemikian rupa, sehingga berbentuk unik, menarik dan berbeda." Karakter menurut Alkitab adalah menjalani hidup kita dihadapan Allah, takut hanya kepada Allah, dan berusaha hanya menyenangkan Tuhan, tidak peduli bagaimana perasaaan kita, atau apa yang mungkin akan dikatakan atau dilakukan orang lain. Secara sederhana karakter adalah melakukan apa yg benar karena hal itu benar.

Melihat perkembangan zaman yang ditandai dengan minimal oleh berkembangnya teknologi dan gaya hidup, ternyata turut merubah karakter anak-anak kristen khususnya yang tinggal di kota-kota besar. Teknologi adalah sesuatu yang positif jika digunakan sesuai dengan fungsinya, tetapi akan menjadi negatif jika digunakan tanpa memperhatikan batasanbatasan normatif. Bayangkan saja pada anak berusia satu tahun yang menghabiskan waktu sekian jam dalam sehari di depan televisi untuk menonton film kartun kesukaannya. Anak- 
anak sekolah dasar lebih banyak menghabiskan waktunya untuk bermain game dari pada belajar atau mengerjakan pekerjaan rumah, bahkan anak-anak ini akan mengalami stres yang tinggi jika akses internet di rumahnya terganggu.

Gaya hidup serba cepat atau instan juga telah merubah karakter seorang anak. Anakanak tidak lagi melihat sesuatu berdasarkan proses, tetapi lebih melihat segala sesuatu dari hasil akhir. Anak-anak tidak peduli bagaimana usaha mencapai sesuatu, yang penting hasil yang diinginkan segera tercapai dengan cara apapun sehingga tidak heran jika ditemukan para pembantulah yang mengerjakan PR seorang anak.

Melihat kenyataan demikian, maka pemerintah dewasa ini sedang giat-giatnya mensosialisasikan pendidikan karakter di sekolah-sekolah hingga perguruan tinggi. Ada tiga kategori orang yang berkenaan dengan karakter. Pertama, ada orang yang berkarakter buruk/jelek/jahat. Kedua, ada yang berkarakter baik/indah (subjektif/objektif). Ketiga adalah orang yang belum berkarakter, ia cenderung labil, polos, dan berubah-ubah.

Pendidikan karakter kristiani bukan sekedar memusatkan diri pada perkembangan sisi manusiawi semata - kita ingat bahwa pada masa kekaisaran Romawi telah terbiasa dengan tindakan aborsi dan pelecehan seksual terhadap anak-anak - melainkan memberi jiwa dalam pendidikan itu sebagai pendidikan religius. Anak bukan hanya dididik menjadi pintar tapi juga beriman. Karakter kristen seyogyanya menjadi perhatian para orang tua kristen dalam membentuk karakter anak-anak mereka. Standar karakter kristen yang hendak dicapai adalah standar yang berdasarkan alkitab, bukan berdasarkan falsafah dunia. Pada tulisan ini, ada tiga hal yang harus diajarkan oleh orang tua kristen pada seorang anak sejak dini agar mereka memiliki karakter kristen yang memberikan teladan.

\section{Pembahasan}

\section{Karakter berdasarkan iman kristen}

Orangtua bertanggung jawab mendidik dan mengajar anak sejak usia dini sehingga terbentuk karakter Kristen yang kuat. Ulangan 6:4-9 menuliskan "Dengarlah, hai orang Israel: TUHAN itu Allah kita, TUHAN itu esa. Kasihilah TUHAN, Allahmu, dengan segenap hatimu dan dengan segenap jiwamu dan dengan segenap kekuatanmu. Apa yang kuperintahkan kepadamu pada hari ini haruslah engkau perhatikan, haruslah engkau mengajarkannya berulang-ulang kepada anak-anakmu dan membicarakannya apabila engkau duduk di rumahmu, apabila engkau sedang dalam perjalanan, apabila engkau berbaring dan apabila engkau bangun. Haruslah juga engkau mengikatkannya sebagai tanda pada tanganmu 
dan haruslah itu menjadi lambang di dahimu, dan haruslah engkau menuliskannya pada tiang pintu rumahmu dan pada pintu gerbangmu."

Anak-anak usia 0 sampai 6 tahun adalah usia dimana otak sedang berkembang dengan pesat hingga 80 persen, dimana banyak orang menyebutnya sebagai masa-masa emas (golden age). Pada usia tersebut otak menerima dan menyerap berbagai macam informasi, yang baik maupun tidak baik. Pada usia ini, hal terpenting yang harus dilakukan oleh orang tua kristen adalah mengisi pikiran anak dengan firman Tuhan karena pembentukan karakter dimulai dengan perubahan pikiran. Bertobat (Metanoia) adalah membersihkan pikiran dan hati dari segala kotoran, sampah, tahayul dan filsafat dunia, dan mengisi pikiran dan hati dengan firman Tuhan. Pikiran yang dikuasai oleh firman Tuhan akan membentuk pola pikir seseorang sesuai dengan kebenaran firman.

Beberapa contoh yang dapat dilakukan oleh orang tua dalam mengisi pikiran anak sesuai dengan firman adalah sebagai berikut:

\section{Mengenalkan alkitab sejak dini.}

Ketika seorang anak belum bisa membaca, maka orang tua berkewajiban membacakan cerita alkitab, menyanyikan atau mendengarkan lagu-lagu rohani yang lyriknya berdasarkan firman sehingga anak dapat mendengarkan dan mengikutinya. Ketika anak sudah bisa membaca, orang tua hendaknya menekankan agar anak membaca alkitabnya setiap hari.

\section{Mengenalkan cara berdoa.}

Orang tua adalah teladan yang baik bagi seorang anak. Karena itu, orang tua yang berdoa akan dilihat oleh anak. Orang tua harus menuntun anaknya untuk berdoa pada saat bangun atau hendak tidur, doa sebelum makan, doa mengucap syukur ketika menerima berkat, berdoa ketika berangkat ke sekolah, bahkan membiasakan anak berdoa jika menginginkan sesuatu yang disukai.

\section{Membiasakan anak beribadah}

Membiasakan anak beribadah pada hari minggu adalah sesuatu yang sangat penting. Anak-anak hendaknya dibiasakan untuk bangun pagi pada hari minggu untuk ke gereja. Tanamkan dipikiran anak bahwa setiap hari minggu adalah hari khusus untuk beribadah kepada Tuhan Yesus dan mengajak anak mengikuti ibadah hari minggu dengan tepat waktu serta membawa alkitab.

\section{Memberikan teladan di dalam perkataan dan perbuatan}

Orang tua hendaknya memberikan contoh di dalam setiap perkataan dan perbuatan. Berkomunikasi dan bertindaklah dengan sopan, ramah, saling menghargai, tidak menang 
sendiri dan adil antara suami dan istri, orang tua dan anak, keluarga dan orang luar. Anakanak sangat mudah meniru perkatan dan perbuatan yang dilakukan orang tua. Karena itu berkata-kata dan bertindaklah dengan penuh hikmat Tuhan.

\section{Membangun kasih di dalam diri anak}

Hal terpenting bagi seorang anak kristen adalah belajar mengasihi Tuhan dan sesama. Anak tidak mungkin mencontoh kasih dari tetangga atau orang lain, tetapi akan mencontoh kasih dari orangtuanya. Karena itu perlihatkanlah sebanyak-banyaknya kasih kita kepada Tuhan, anggota keluarga dan sesama, bukan berlebihan mengasihi diri sendiri, mengasihi harta benda, jabatan dan lain-lain.

\section{Karakter berdasarkan teladan Yesus}

Dasar kedua yang digunakan untuk membentuk karakter anak kristen adalah dengan mengajarkannya sesuai dengan keteladanan Tuhan Yesus. Seorang anak tentu tidak mengerti pelajaran yang terkandung dari tindakan Tuhan Yesus di dalam Alkitab. Karena itu mutlak diperlukan bimbingan orang tua di dalamnya. Orang tua tidak boleh memberikan kepercayaan penuh kepada guru sekolah minggu atau pendeta dalam memperkenalkan teladan Yesus. Sebaliknya orang tualah yang harus memiliki inisiatif awal untuk memperkenalkan keteladan Yesus.

Berikut adalah beberapa contoh keteladanan Yesus yang dapat diajarkan kepada anak, agar mereka dapat memiliki karakter Kristus.

\section{Kerendahan hati-Nya}

Kerendahan hati adalah kebalikan dari keangkuhan. Kerendahan hati mengajarkan agar seseorang membuang egosentrisnya dan memiliki hati sebagai hamba. Matius 20:26-27 " Tidaklah demikian di antara kamu. Barangsiapa ingin menjadi besar di antara kamu, hendaklah ia menjadi pelayanmu, dan barangsiapa ingin menjadi terkemuka di antara kamu, hendaklah ia menjadi hambamu.

\section{Pengendalian diri-Nya}

Belajar mengendalikan diri adalah sesuatu yang luar biasa. Yesus telah mengajarkan pada pengikut-pengikut Nya ketika Ia dicobai di padang gurun, tapi pada akhirnya Yesus menang. Matius 4:1 "Maka Yesus dibawa oleh Roh ke padang gurun untuk dicobai iblis."

\section{Kebaikan-Nya}

Kebaikan Tuhan Yesus tidak diragukan lagi. Ketika anak-anak diminta datang kepadaNya (Mark. 10:13-16) maka Tuhan memeluk dan memberkati mereka semua. Tuhan tidak hanya mempunyai berita tentang kasih karunia dan penebusan, tetapi Dia memiliki tindakan 
untuk menyatakan kasih, sehingga semua orang dapat melihat. Nyatakanlah kebaikan Yesus kepada orang lain melalui hidup kita. Sifat yang semakin ditelan oleh dunia ini harus dimunculkan dari orang-orang percaya untuk menjadi terang dan garam dunia.

\section{Keteguhan-Nya}

Ketika Yesus sedang disidang oleh Pilatus, Yesus memiliki keteguhan hati yang luar biasa. Dia tidak goyah oleh ancaman, kekerasan, fitnahan atau hal apapun. Yesus tidak pernah tunduk pada dunia walapun harus disalib. Anak-anak sejak dini harus dilatih memiliki hati yang teguh untuk mempertahakan imannya dan teguh melakukan kebenaran. Iman tidak dapat ditukar dengan seluruh kekayaan dunia, atau oleh berbagai kesulitan dan ancaman.

\section{Objektivitas-Nya}

Keadilan dan objektifiatas Yesus terlihat ketika Ia bertemu dengan seorang wanita Samaria yang sedang menimba air (Yoh 4:9). Yesus tetap ramah dan sabar sehingga bisa tetap objektif menilai wanita Samaria. Dengan demikian kebenaran dapat disampaikan. Melatih anak-anak memiliki keadlian dan objektif adalah sesuatu yang membanggakan. Di dunia ini anak-anak diperhadapkan dengan ketidakadilan hukum serta keegoisan dan kelobaan manusia, tetapi anak yang memiliki karakter Yesus akan tetap adil dan objektif.

\section{Empati-Nya}

Satu ayat pendek yang menggambarkan empati Yesus dapat dilihat di Yohanes 11:35 "Maka menangislah Yesus." Peristiwa ini terjadi ketika Lazarus meninggal dan sebagai seorang sahabat, Yesus merasakan kesedihan sebagaimana dirasakan oleh Maria saudaranya. Sikap empati akan membuka diri untuk berempati pada orang lain, bersedia mendengarkan orang lain mengungkapkan perasaannya, fleksibel untuk sesuatu yang tidak prinsip, bersedia terlibat dan mau mengerti akan suatu keadaan.

\section{Karakter berdasarkan pola hidup orang tua}

Orang terdekat bagi seorang anak adalah orang tuanya. Orang tua mengenal dan menerima seorang anak sebagaimana ia diciptakan. Setiap anak berbeda, karena itu orang tua harus melihat seorang anak dari sudut pandang Tuhan, bukan sudut pandang orang tua. Ketika kita menerima seorang anak, kira juga harus menerima kekurangan dan kelebihannya karena gen yang dibawa.

Hal lain yang patut menjadi perhatian adalah bagaimana kehidupan orang tua mempengaruhi anaknya. Anak tidak dapat memilih ia berasal dari keluarga kaya atau miskin, keluarga yang mengasihi atau yang tidak bertanggungjawab, keluarga yang ramah atau pemarah. 
Pembentukan karakter kristen sangat membutuhkan kasih. Kasih yang dimaksud tentu saja tidak berarti memberikan atau mengabulkan segala permintaan anak. Kasih yang benar harus disertai dengan disiplin. Ibrani 12:6 berkata bahwa "Karena Tuhan menghajar orang yang dikasihi-Nya, dan Ia menyesah orang yang diakui-Nya sebagai anak."

\section{Kasih}

Kasih adalah sesuatu yang abstrak tetapi dapat dirasakan. Karena itu sangat mungkin bagi seorang anak untuk merasakan bahwa ia dikasihi, tidak dikasihi atau menerima kasih yang kurang tepat. Kasih yang kurang tepat akan menyebabkan salah sasaran dalam membentuk karakter anak, diantaranya yaitu:

\section{Kasih yang bersifat memiliki}

Orang tua yang "terlalu mengasihi" cenderung menerapkan kasih yang memiliki atau mengikat. Kasih demikian mendorong anak untuk bersandar kepada orang tua secara berlebihan. Akibatnya anak-anak menjadi tidak mandiri serta menciptakan ketergantungan yang tidak tepat.

\section{Kasih yang bersifat menggantikan}

Kasih jenis ini menekankan anak untuk mencapai sesuatu yang dicita-citakan oleh orang tua tetapi yang belum pernah terealisasi. Kasih jenis ini adalah kasih yang sangat berbahaya karena membatasi tingkah laku dan bakat anak serta hanya memuaskan orang tua.

\section{Kasih yang bersifat memutarbalikkan peranan}

Di sini orang tua bertukar peran dengan anak demi kepuasan diri sendiri. Anak dituntut memberikan perhatian kepada orang tua karena faktor kesepian, dituntut untuk dimengerti keadaan orang tua. Akibatnya anak dilatih bertanggungjawab untuk sesuatu yang tidak seharusnya.

\section{Kasih yang bersifat pilih kasih.}

Umumnya anak yang cerdas, cantik dan menarik akan mendapat kasih yang lebih besar dari pada anak lain. Seharusnya anak yang secara fisik memiliki kekurangan yang mendapat prioritas kasih yang lebih besar. Kasih seperti ini sering kali menimbulkan masalah, misalnya kasus Ishak yang memilih kasih terhadap Esau dari pada Yakub yang menimbulkan masalah dalam keluarga besar. 


\section{Disiplin}

Kasih berhubungan dengan menghajar atau disiplin. Tanpa kasih tidak ada disiplin yang sesungguhnya. Sebaliknya disiplin yang sesungguhnya harus didasarkan pada kasih. Disiplin memiliki beberapa pengertian:

\section{Faktor pengarahan}

Disiplin mengandung arti pengarahan akan hal-hal yang benar dan salah. Pembentukan karakter kristen berdasarkan pondasi alkitab sebenarnya ingin menyatakan kepada kita apa yang benar dan apa yang salah. Karena itu jika kita ingin anak-anak hidup dengan standar yang benar maka kita harus sungguh-sungguh mengarahkan sesuai dengan firman Tuhan.

\section{Faktor pengendalian}

Disiplin juga berarti pengendalian diri. Manusia dilahirkan dalam dosa, maka sejak lahir sdh terlihat benih-benih atau tabiat dosa. Seorang bayi yang lahir sudah memiliki sifat keegoisan untuk segera dipuaskan. Karena itu dengan orang tua harus menolong anakanaknya mengendalikan diri dan dengan partolongn Tuhan, jiwa mereka diubah menuju hidup baru di dalam Kristus.

\section{Faktor konsistensi}

Disiplin haruslah dijalankan dengan konsisten. Konsisten antara suami dan istri dalam mendidik anak sangatlah menolong anak untuk tetap berada dijalur yang diinginkan. Demikian pula konsisten antara perkataan dan tindakan, sehingga tidak menciptakan kebingungan pada diri anak, mana yang dikatakan tidak sesuai dengan apa yang dilakukan.

\section{Faktor penghajaran}

Disiplin kadang-kadang juga memiliki pengertian penghajaran. Sekilas kata "menghajar" kedengarannya sangat kasar dan menakutkan, tapi sebagaimana Tuhan, orang tua pasti memiliki kasih yang besar sehingga tidak sembarangan dalam menghajar anak. Pengertian ini harus dilihat dalam konteks pendisiplinan, bukan berkonatasi negatif yang mencelakakan. Bagi orang dewasa, penghajaran Tuhan mungkin melalui khotbah yang menegur dosa, dengan masalah, kegagalan bahkan dengan penyakit, tetapi tentu saja tidak semuanya merupakan hukuman dari Tuhan. Bagi seorang anak, menghajar diperlukan ketika anak tidak mematuhi orang tua yang sesuai dengan kebenaran firman Tuhan. Jika sangat diperlukan, berikan satu kali pukulan pada bagian pantat anak, kemudian berikan pengertian mengapa hal itu dilakukan oleh orang tua dan akhiri dengan memeluk serta mencium anak tersebut sambil berkata bahwa kita sangat sayang dengan dia. Dengan demikian anak akan mengerti dan tidak memiliki akar pahit dengan orang tua. 


\section{Kesimpulan}

Membentuk karakter kristen anak pada keluarga kristen tidak otomatis terjadi karena kita beragama kristen. Diperlukan banyak perjuangan, air mata, doa dan harga yang harus dibayar. Tapi sebagai orang tua yang bertanggung jawab kepada Tuhan, bagaimanapun sulitnya, hal ini harus tetap dilakukan. Karena itu tetaplah andalkan Tuhan dan serahkan anakanak sepenuhnya kepada Tuhan. Bersamaan dengan itu, hendaklah orang tua juga terus memperbaharui diri di dalam Tuhan.

\section{Daftar Pustaka}

Setiawati, Mary \& Stephen Tong. Seni Membentuk Karakter Kristen, Hikmat Guru \& Ayah Bunda, Momentum : Lembaga Reformed Injili Indonesia, 2012,

Carter, Les. Pembentukan Karakter, Bagaimana Mencerminkan Sifat-Sifat Kristus? Semarang: Yayasan Baptis Indonesia, 2001

Koesoema A, Doni. Pendidikan Karakter, Strategi Mendidik Anak di Zaman Global, Jakarta: Grasindo, 2007 